\title{
PROCESSOS DE FORMAÇÃO DE NEOLOGISMOS NO INSTAGRAM
}

\author{
PROCESSES OF NEOLOGISM FORMATION ON \\ INSTAGRAM
}

\author{
Mirella De Souza Balestero \\ Universidade Estadual Paulista, Araraquara, São Paulo, Brasil \\ msbalestero@gmail.com \\ Camila Bordonal Clempi \\ Universidade Estadual Paulista, Araraquara, São Paulo, Brasil \\ camilabordonal@yahoo.com.br \\ Daniel Soares Da Costa \\ Universidade Estadual Paulista, Araraquara, São Paulo, Brasil \\ dan.fono@gmail.com
}

Resumo: Neste artigo, temos como objetivo estudar os processos de formação de neologismos inseridos no meio digital Instagram, em 2017, a partir das seguintes palavras: sabadar, pleníssimo, estranhice, carnistas, contatinho, pré-nada, baile, stalker, stalkeio e meme. Valemonos dos fundamentos teóricos da morfologia do português e verificamos o possível registro das palavras selecionadas nos dicionários Houaiss (2009), Aurélio (FERREIRA, 2009) e Michaelis (2017), além da aceitação da comunidade linguística. Como resultado de nossa pesquisa, neologismos produzidos pelo processo de derivação sufixal foram os casos mais produtivos.

Palavras-chave: Morfologia; Formação de Palavras; Neologismo

Abstract: This paper aims to study neologism formation processes available on digital media Instagram, in 2017, from the words sabadar, plenissimo, estranhice, carnistas, contatinho, prénada, baile, stalker, stalkeio e meme. We based on theoretical assumptions of Portuguese morphology and we checked possible record of these selected words in the dictionaries Houaiss (2009), Aurélio (FERREIRA, 2009), and Michaelis (2017), besides acceptance of the language community. As a result of our research, neologisms produced by suffix derivation process were the most productive cases.

Keywords: Morphology; Word Formation; Neologism 


\section{O CARÁTER DINÂMICO DA LIÍNGUA}

É sabido que as línguas variam e, em consequência, podem mudar. Segundo Coseriu $(1979$, p. 63, grifo do autor) "a língua muda justamente porque não está feita, mas, sim, faz-se continuamente pela atividade linguística". Na mesma esteira, Martelotta $(2011$, p. 28) salienta que

(...) as línguas não têm finalidade em si mesmas, os humanos as desenvolveram para promover a comunicação entre eles. Ora, os homens evoluem e mudam suas concepções acerca do mundo em que vivem, que, consequentemente, acaba mudando com eles. É natural, portanto, que o homem modifique sua forma de falar sobre esse mundo e isso acaba motivando as mudanças estruturais que as línguas sofrem com o passar do tempo. Em outras palavras, as línguas se adaptam aos novos tempos.

Tomamos como objeto de estudo a unidade lexical, que nasce da necessidade dos sujeitos em nomear algo em determinadas situações e épocas. Com o passar dos anos, as unidades lexicais usadas para nomear um determinado objeto, por exemplo, entram em desuso e/ou surgem novas significações.

O léxico, isto é, o conjunto de unidades lexicais da língua, tem um caráter instável, na medida em que as mudanças ocorrem, e estável, uma vez que a unidade é registrada em obras lexicográficas. A constante renovação lexical, ligada a fatores linguísticos (estruturais) ou extralinguísticos (sociais), documenta as concepções de mundo de uma dada comunidade linguística em um dado momento. Por isso, dizemos que o léxico tem um caráter sociocultural, pois é na/pela sociedade que as atividades linguísticas vão se concretizar e é no léxico que as visões de mundo são materializadas. Se a sociedade está em constante movimento, a língua também está, portanto, novas palavras são frequentemente inseridas no sistema linguístico.

Conforme Alves (1990, p. 5), “o acervo lexical de todas as línguas vivas se renova. Enquanto algumas palavras deixam de ser utilizadas e tornam-se arcaicas, uma grande quantidade de unidades léxicas é criada pelos falantes de uma comunidade linguística”. Mas como são criadas novas palavras?

Para responder a essa pergunta nos valemos, ao longo do artigo, dos pressupostos teóricos da morfologia do português na tentativa de explicar os neologismos digitais presentes no Instagram. $\mathrm{Na}$ internet, encontramos, em alguns contextos, uma escrita intencional, de linguagem híbrida, que traz nuances da modalidade falada da língua. Nesse sentido, o Instagram é uma rede favorável para detectar palavras neológicas.

A importância de se estudar os neologismos resulta da possibilidade do sistema linguístico em formar novas palavras e da capacidade do falante em renovar o léxico a todo instante, os quais, na literatura, chamamos de produtividade e criatividade lexical, respectivamente. Conforme afirma Cabré (1993, p. 452, tradução nossa) “(...) na neologia devemos contar, necessariamente, com a dinâmica das línguas e a liberdade de seus falantes, que vão muito além dos organismos e dos planos"1, ou melhor, das regras padronizadas de uma língua. Dessa forma, os neologismos podem ou não seguir a estrutura da língua portuguesa, se valendo, ocasionalmente, de mecanismos menos comuns ou até mesmo emprestados de outra língua, os quais abordaremos mais à frente.

Portanto, a língua "não se impõe ao falante, mas se lhe oferece: o falante dispõe dela para realizar sua liberdade expressiva" (COSERIU, 1979, p. 64, grifo do autor). A seguir,

\footnotetext{
1 “(...) en neología debemos contar, necesariamente, con la dinámica de las lenguas y la libertad de sus hablantes, que actúan más allá de los organismos y los planes” (CABRÉ, 1993, p. 452).
} 
faremos um levantamento teórico do que diz a literatura sobre os processos de formação de neologismos, de modo a melhor compreender as formas de inovar o léxico.

\section{INOVAÇÃO LEXICAL}

Há muitas maneiras de inovar o léxico de uma língua. $\mathrm{Na}$ maioria das vezes, o indivíduo segue alguma das regras internas do sistema, aplicando uma das prescrições de formação de palavras já existentes na língua. No entanto, algumas das palavras criadas geram um efeito de estranhamento aos falantes quando estes fogem das regras morfológicas padronizadas e quando se utilizam de uma construção não comum.

Tratamos, neste artigo, apenas as lexias neológicas que seguem as regras de formação de palavras segundo a morfologia padrão do português, visto que foram as que ocorreram no nosso corpus, selecionadas a partir de critérios explicitados na seção "Análise de dados". No entanto, reconhecemos a dinamicidade dos neologismos e a necessidade de descrevê-los na medida em que a língua se altera e se atualiza.

Para melhor delimitar o tema proposto, definimos como neologismo tudo o que é novo na língua, ou seja, toda unidade recente no léxico e que, consequentemente, ainda não se encontra dicionarizada. Neologia, do grego neo- (novo) e -logos (noção), é definido pela Norma ISO/FDIS 1087-1 como "termo de criação recente ou emprestado há pouco tempo de uma língua estrangeira ou de uma outra área do conhecimento". Segundo Alves (1990, p. 5), dá-se o nome de neologia ao processo de criação lexical, e neologismo ao produto resultante desse processo. Para Ferraz (2008), a neologia lexical é o processo linguístico que produz formas e significados inéditos no léxico. Além disso, Martins (2015) elucida que o resultado do processo de neologia é conhecido como neologismo que pode entrar no sistema linguístico, se aceito e utilizado pelos falantes.

Mas como identificar um neologismo? Apresentamos, aqui, alguns critérios utilizados por autores da área para conceituar o termo na língua.

A partir do olhar de Guilbert (1975), sobre como identificar um neologismo, Correia e Almeida (2012) afirmam que é preciso levar em conta o sentimento de novidade, isto é, o falante determina que não conhece aquela palavra e já a detecta como nova no sistema linguístico. Esse critério é válido, mas não suficiente, visto que a unidade pode ser apenas desconhecida daquele indivíduo e/ou já estar estabilizada, portanto, registrada em algum dicionário. O critério mais utilizado é o de caráter lexicográfico, cuja regra é considerar neologismo tudo aquilo que não está dicionarizado. Contudo, é importante frisar que não há meios de atualizar uma obra lexicográfica na medida em que a língua se atualiza, por motivos culturais, políticos, financeiros, dentre outros.

De acordo com Correia e Almeida (2012), devemos levar em consideração dois aspectos (novidades) para identificar um neologismo, que são: novidade formal (novo significante) e novidade semântica (uma nova acepção para uma palavra já existente). Vale ressaltar que todos os tipos de neologismos ocorrem no sistema linguístico, sendo alguns tipos mais comuns que outros. Sandmann (1997) considera três recursos para a ampliação do léxico, dentre eles: (i) empréstimo; (ii) criação a partir do nada, ou seja, "a partir de fonemas ou sílabas e não de palavras ou morfemas já existentes na língua" (SANDMANN, 1997, p. 22); e, por fim, o mais comum (iii) a palavra criada a partir de morfemas preexistentes (op cit., p. 23). Sobre esse último recurso, acrescenta Alves (1990, p. 5) que “(...) o léxico português, basicamente de origem latina, tem ampliado seu acervo por meio de mecanismos oriundos do latim, a derivação e a composição".

Refletir, portanto, sobre a maneira como as palavras são formadas se faz relevante. A partir dos estudos que embasam as teorias lexicais e morfológicas, é pertinente afirmar que toda 
palavra deriva de processos disponíveis na língua (do mesmo sistema ou de outro), isto é, os neologismos são sempre construídos a partir de algum mecanismo de formação de palavra.

\subsection{MECANISMOS DE PRODUTIVIDADE LEXICAL}

As palavras podem ser criadas por três tipos de mecanismos mais comuns: (i) construção de palavras por meio de regras inerentes ao sistema da língua; (ii) atribuição de novos significados a palavras já existentes; e (iii) importação de palavras pertencentes a outras línguas. Em alguns casos, os neologismos resultam da combinação de dois ou mais tipos de processos.

Os processos mais produtivos para a inovação lexical, na língua portuguesa, estão sintetizados no Quadro 1 abaixo:

Quadro 1 - Principais processos para formação de neologismos.

\begin{tabular}{ccc}
\hline NEOLOGISMOS & CARACTERÍSTICAS & $\begin{array}{c}\text { PROCESSOS } \\
\text { DISPONÍVEIS }\end{array}$ \\
\hline Neologismo formal & $\begin{array}{c}\text { construção de palavras por } \\
\text { meio de regras já inerentes ao } \\
\text { sistema da própria língua }\end{array}$ & $\begin{array}{c}\text { derivação } \\
\text { composição }\end{array}$ \\
\hline Neologismo semântico & $\begin{array}{c}\text { atribuição de novos } \\
\text { significados a palavras já } \\
\text { existentes }\end{array}$ & $\begin{array}{c}\text { metáfora } \\
\text { metonímia }\end{array}$ \\
\hline Neologismo importado & $\begin{array}{c}\text { importação de palavras } \\
\text { pertencentes a outras línguas }\end{array}$ & $\begin{array}{c}\text { empréstimo } \\
\text { estrangeirismo }\end{array}$ \\
\hline
\end{tabular}

Fonte: elaborado pelos autores, baseado em Alves (1990), Sandmann (1997) e Correia e Almeida (2012).

Os processos de formação de palavras fazem parte do estudo da morfologia lexical, área que analisa os recursos morfológicos na produção de palavras. Nas línguas românicas, em geral, os processos mais conhecidos são por: a) derivação: quando um vocábulo é criado por meio do acréscimo de afixos, sendo eles prefixos ou sufixos, a uma só base; b) composição: quando um vocábulo é criado a partir da combinação de duas ou mais bases. Segundo Alves (1990, p. 5), uma das maneiras de formação de neologismos corresponde aos "mecanismos oriundos da própria língua, os processos autóctones, como a derivação e a composição". Em fase de novidade, portanto, as palavras criadas a partir da derivação e composição consistem no que chamamos de neologismo formal.

Em relação ao processo de derivação, a estrutura da língua portuguesa nos permite a criação lexical a partir de cinco tipos, são eles: derivação prefixal, derivação sufixal, derivação parassintética, derivação regressiva e derivação imprópria (conversão).

$\mathrm{Na}$ derivação prefixal, um prefixo é adicionado a uma base, como em in + grato $>$ ingrato e na derivação sufixal, um sufixo é adicionado a uma base, como em leal + dade $>$ lealdade. Quando os afixos são adicionados simultaneamente à base, ocorre a derivação parassintética, sendo o caso da palavra in + feliz + mente $>$ infelizmente.

$\mathrm{O}$ ato de se retirar um sufixo da base da palavra de origem constitui o que chamamos de derivação regressiva. Segundo Kehdi (2003, p. 22), "o maior número de derivados regressivos é constituído de substantivos deverbais", que se trata de um tipo de processo de 
conversão, transformando verbos em nomes de ação. Um exemplo é "lutar" (verbo), que resulta em "luta" (nome), cujo significado do nome resultante da derivação regressiva se dá apenas pelo significado do verbo que lhe serviu de base. No entanto, esse processo de derivação não parece ser muito produtivo no português contemporâneo.

A conversão, denominada derivação imprópria pela gramática tradicional, é o processo cuja palavra, de acordo com o contexto discursivo, sofre alterações de significado e da classe morfológica à qual pertence. "Andar", por exemplo, é classificada morfologicamente como verbo, mas se utilizada em contextos como, por exemplo, "Vamos ver como será o andar da carruagem neste semestre", a palavra destacada é substantivada.

Além disso, o processo de derivação nos permite formar palavras a partir da mudança de classe gramatical, ou seja, por meio de afixos, uma palavra de uma determinada classe pode dar origem a outra, de classe diferente. Sobre essa questão, Basilio (2004, p. 28) estabelece que

há dois motivos principais para a mudança de classe, que decorrem da dupla função do léxico de designar entidades e fornecer elementos básicos para a construção de enunciados. Um deles é a necessidade de usar palavras de uma classe em estruturas gramaticais que exigem palavras de outra; o segundo é a necessidade de aproveitar conceitos ocorrentes em palavras de uma classe em palavras de outra classe. O primeiro caso corresponde à motivação gramatical, o segundo, à motivação semântica.

De acordo com as motivações do falante, a mudança de classe na formação de palavras se efetua em qualquer tipo de derivação a partir de substantivos, adjetivos, verbos e advérbios.

Para concluir, Silva-e-Souza e Koch (2012, p. 52) afirmam que, na derivação, "a maior ou menor produtividade do afixo auxilia o falante não só a formar ou aceitar determinadas palavras, rejeitando outras, como também interpretar determinados vocábulos como morfologicamente complexos ou simples". Isso implica dizer que novas palavras, para serem aceitas, quase sempre, passam por uma avaliação inconsciente dos sujeitos.

Já no processo de composição, por outro lado, os elementos combinados perdem sua significação própria e as bases, quando atreladas, operam uma "fusão semântica" (SOUZA-ESILVA; KOCH, 2012, p. 54), criando, assim, uma nova palavra. Encontramos dois tipos de composição no português, relacionadas ao aspecto fonológico da palavra: a justaposição e a aglutinação. No primeiro caso, os elementos constituintes mantêm sua unidade fonológica, enquanto, no segundo, os elementos se fundem e apenas o acento de um dos constituintes é conservado. São exemplos de justaposição e de aglutinação as palavras "paraquedas" (para + quedas) e "fidalgo" (filho + de + algo), respectivamente.

Por neologismo semântico, entendemos o processo em que as unidades lexicais já existentes na língua adquirem novos significados. Esse fenômeno concebe às palavras um caráter polissêmico, contribuindo para a economia do sistema linguístico. Há diversos mecanismos para uma palavra apresentar mais de um significado, dentre eles, a metáfora e a metonímia. Grosso modo, temos uma metáfora quando fazemos uma comparação e uma metonímia no momento em que há uma relação de parte/todo. São exemplos de metáfora e metonímia ${ }^{2}$ as construções hipotéticas "você é uma flor" e "bebi um copo de café de manhã", respectivamente.

Também o contato linguístico pode se refletir no léxico dos falantes (FERRAZ, 2008), pois, quando uma palavra de um sistema passa a ser utilizada em outro e não se integra imediatamente à língua receptora, essa palavra é sentida como uma novidade pelos falantes, é o que denominamos neologismo importado, a saber, empréstimo e estrangeirismo (cf. Quadro

\footnotetext{
${ }^{2}$ Conferir em Correia e Almeida (2012, p. 64).
} 
1). A seguir, faremos uma breve explanação sobre ambos os conceitos a fim de melhor compreendê-los.

Estudiosos, como Alves (1990) e Câmara Jr. (2002) [1973], definem empréstimo como o processo pelo qual a unidade lexical de outro sistema linguístico se incorpora e se adapta ao léxico da língua de chegada, a exemplo, no português, da palavra shampoo $\rightarrow$ xampu (grafia). Já Rocha (2008), vale-se de critérios fonéticos e fonológicos para a definição de empréstimo. De acordo com o autor, a unidade lexical emprestada apresenta um fonema, ou sequência de fonemas, que causa estranhamento ao sistema da língua portuguesa, como as palavras outdoor e marketing. A noção de empréstimo de Rocha (2008) equivale ao conceito de estrangeirismo definido pelos autores supracitados.

Dizemos que uma unidade é resultado do processo de estrangeirismo quando o vocábulo não é integrado à língua de chegada, "(...) conservando os fonemas, a flexão e a grafia da língua de origem" (CÂMARA JR., 2002 [1973], p. 111). Conforme Alves (1990, p. 72), “o elemento estrangeiro, empregado em outro sistema linguístico, é sentido como externo ao vernáculo dessa língua". Destacamos, portanto, que o estrangeirismo pode acontecer em diversos níveis: morfológico, fonológico e semântico. Nesse sentido, um exemplo de estrangeirismo seria poledance.

Desse modo, novas palavras são criadas a partir da necessidade do falante em se expressar cotidianamente em novas realidades e novos contextos. Além disso, "o estudo da neologia lexical de uma língua permite-nos analisar a evolução da sociedade que dela se utiliza, pois as transformações sociais e culturais refletem-se nitidamente no acervo léxico dessa comunidade" (ALVES, 1990, p. 87), causando efeitos de estranhamento, ironia, cor local, humor etc. (idem, p. 86).

Descreveremos, na próxima seção, nosso material de análise, pois muito nos revela sobre as novas produções de expressão linguística na era tecnológica.

\section{NEOLOGISMO NO INSTAGRAM}

O Instagram é uma rede de compartilhamento de fotos e vídeos, em formato de aplicativo para celular e com acesso também pelo computador, tendo um nascimento relativamente novo no mundo digital. Criado em 2010, é uma das maiores redes sociais utilizadas na web, ao menos no Brasil, resultando muito popular, principalmente entre os jovens. Além de compartilhar, os usuários podem interagir entre si por meio das funções disponíveis no app, tais como, seguir outros perfis e ainda curtir e comentar fotos publicadas por outros seguidores. Além dos perfis pessoais, encontramos diversos outros tipos, dentre eles, perfis de bandas, lojas, empresas etc., e também aqueles de caráter humorístico, como memes ${ }^{3}$ e/ou vídeos tratando de assuntos do cotidiano, o que gera humor.

No Instagram, o perfil de humor "Chapolin Sincero" (@chapolinoficial) instigou-nos na busca por neologismos. Com mais de onze milhões de seguidores, sendo a grande maioria composta por adolescentes, o perfil publica fotos do famoso personagem da televisão Chapolin Colorado, com frases de linguagem típica que caracteriza o "internetês" - frases retiradas da internet, sobretudo em redes sociais.

\footnotetext{
${ }^{3}$ Fontanella (2009, p. 9) define memes como um gênero textual em que "idéias, brincadeiras, jogos, piadas ou comportamentos se espalham através de sua replicação de forma viral, caracterizados pela repetição de um modelo formal básico a partir do qual as pessoas podem produzir diferentes versões do mesmo meme". Trata-se de representar determinado objeto no mundo a partir dos aspectos sociais, culturais, temporais etc. Dessa forma, “estudar os memes (...) significa compreender que sua replicação em determinados ambientes encontra-se atrelada a valores simbólicos, culturais e sociais, contribuindo para a formação de grupos de interesses compartilhados" (BARRETO, 2015, p. 10).
} 
Esse contexto nos sugere o possível aparecimento de novas formas no léxico do português. Além disso, apesar de os neologismos surgirem primeiramente na fala, para depois alcançarem a escrita, não podemos desconsiderar que a escrita reflete também as práticas sociais dos sujeitos (MARCUSCHI, 2007) e que, com a internet, há novos meios de interação e novas situações em que é necessária a renovação lexical.

\section{ANÁLISE DE DADOS}

Para a obtenção dos dados, valemo-nos de dois critérios de reconhecimento de neologismos: a novidade (CORREIA; ALMEIDA, 2012), partindo de nossa intuição, como linguistas e falantes do português, para detectar possíveis palavras neológicas no sistema; e a consulta a obras lexicográficas.

Coletamos os possíveis casos, frequentemente citados, nas frases das figuras a seguir, publicadas em 2017, no Instagram do referido perfil e verificamos o número de curtidas de cada imagem selecionada (acima de $100 \mathrm{mil}$ ) a fim de evidenciar a aceitação e o uso recorrente das palavras pelo público. Além disso, verificamos se as palavras selecionadas estavam ou não registradas nas seguintes obras: dicionários digitais Aurélio (FERREIRA, 2009) e Michaelis $(2017)^{4}$ e dicionário eletrônico Houaiss $(2009)^{5}$. Procuramos obras lexicográficas atuais e de diferentes meios (digital e eletrônico) para tal verificação. Concluímos, a partir de nossa busca, que nenhuma das palavras está dicionarizada, pelo menos, até o momento em que a pesquisa foi realizada.

Para este trabalho, centramos nossa análise dos dados nas seguintes palavras neológicas do português: sabadar, pleníssimo, estranhice, carnistas, contatinho, pré-nada, baile, stalker, stalkeio e meme. Vejamos o primeiro neologismo - sabadar - por nós selecionado:

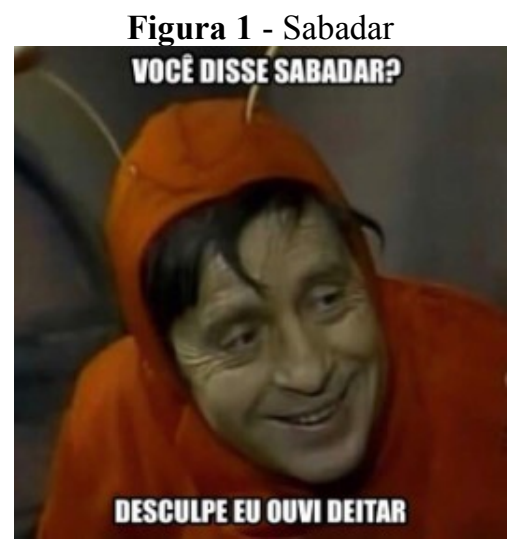

Fonte: Instagram.

O neologismo formal "sabadar", mencionado na Figura 1, é formado a partir do processo de derivação sufixal, sendo que, ao substantivo comum masculino "sábado", é acrescido o sufixo verbal '-ar', ocorrendo o processo morfofonológico de supressão da vogal temática 'o', conforme demonstramos: [sábado $]_{\text {substantivo }}+[\text { ar }]_{\text {sufixo }}>[\text { sabadar }]_{\text {verbo }}$.

Nesse caso, verificamos analogia com outros verbos da mesma conjugação, por exemplo, "deitar", que é também citado na Figura 1. Segundo Basilio (2004), a formação de verbos em '-ar', a partir de substantivos, é muito comum na língua portuguesa e acontece, em maior número, em contextos informais, com o objetivo de aproveitar a informação semântica

\footnotetext{
${ }^{4}$ Consulta nos sites: https://dicionariodoaurelio.com/ e http://michaelis.uol.com.br/moderno-portugues/.

${ }^{5}$ Disponível em CD-ROM.
} 
contida no substantivo, designando uma ação. "Sabadar", nesse contexto, significa a ação de curtir, sair, festejar aos sábados, em contraste com "deitar" que nos sugere o ato de relaxar, ficar em casa.

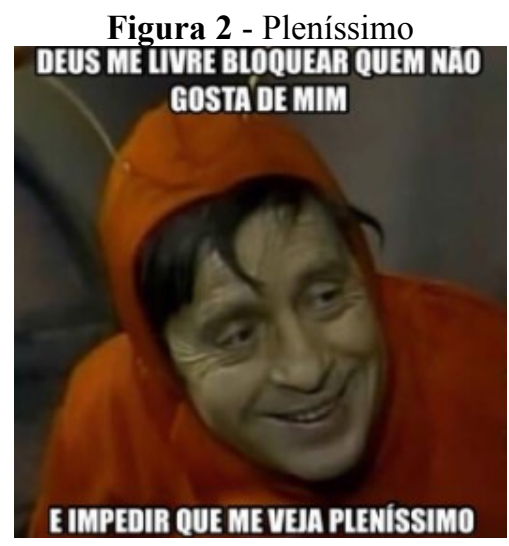

Fonte: Instagram.

"Pleníssimo" (Figura 2), neologismo formal por derivação sufixal, é resultado do acréscimo do sufixo '-íssimo' ao adjetivo "pleno": [pleno] $]_{\text {adjetivo }}+[\text { [íssimo }]_{\text {sufixo }}>$

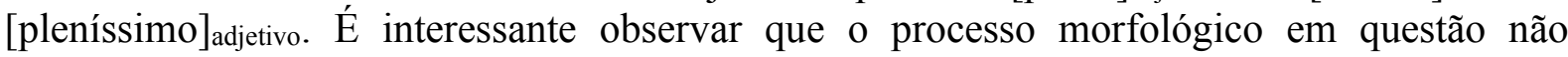
modificou a classe gramatical (adjetivo) da palavra-base - processo comum na língua portuguesa -, o que ocorreu foi apenas uma intensificação do adjetivo "pleno". Trata-se, portanto, do superlativo absoluto do adjetivo que expressa o sentido de estar bem, maravilhoso, radiante, feliz.

Figura 3 - Estranhice

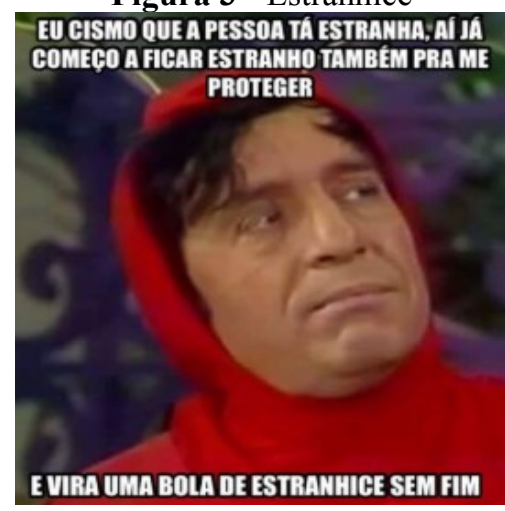

Fonte: Instagram.

A Figura 3 apresenta um neologismo formal - "estranhice" -, formado por meio do processo de derivação sufixal [estranho $]_{\text {adjetivo }}+[\text { ice }]_{\text {sufixo }}>[\text { estranhice }]_{\text {substantivo, }}$, como é o caso dos substantivos solteirice, burrice, velhice etc. O sufixo '-ice', nesse sentido, atribui à palavra derivada a noção de estado, assim, na Figura 3, "estranhice" se refere à condição de ser ou estar estranho. É possível dizer, também, que a expressão "bola de estranhice" faz analogia a "bola de neve" 6 , lexia complexa que representa o sentido da palavra como um todo, de confusão e/ou problema.

\footnotetext{
6 Importa destacar que a expressão "bola de neve" nada mantém relação direta com a palavra neológica "estranhice". Fizemos tal associação devido ao contexto discursivo em que está inserida nesse caso em específico. Ainda, o uso de "estranhice" pelos falantes pode não ser restrito à expressão "bola de estranhice", todavia, não encontramos dados empíricos para a comprovação.
} 
Figura 4 - Carnistas

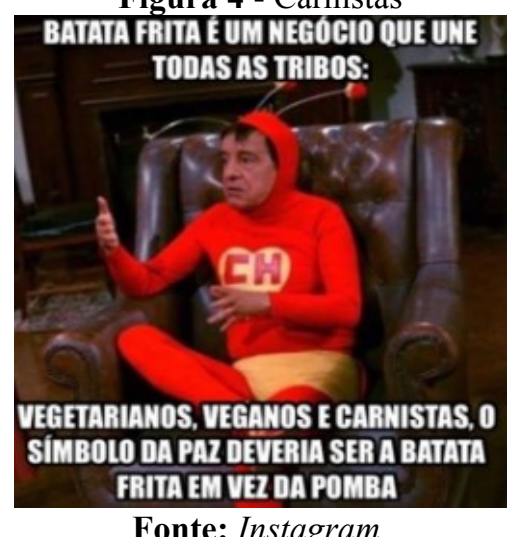

"Carnista" (Figura 4) consiste em um neologismo formal produzido por sufixação, isto é, à base 'carne' é acrescentado o sufixo '-ista': [carne $]_{\text {substantivo }}+[\text { ista }]_{\text {sufixo }}>[\text { carnista }]_{\text {adjetivo, }}$ de modo tal que "carnista" se refere ao indivíduo que segue um regime alimentar, no caso, uma pessoa "carnista" é aquela que come carne e outros tipos de alimentos, ou só carne, contrapondo-se aos vegetarianos e veganos. Basilio (2004, p. 74) esclarece que "os principais processos de formação de nomes de agente a partir de substantivos correspondem à adição dos sufixos '-ista' e '-eiro'. A forma "carneiro", nesse caso, é bloqueada, visto que essa palavra já existe com outro sentido. Verificamos, mais uma vez, o mecanismo da analogia na construção semântica da palavra, contudo, percebe-se que esse argumento não justifica a escolha de "carnistas" e não "carnanos", "carnerianos" ou qualquer outra possível construção.

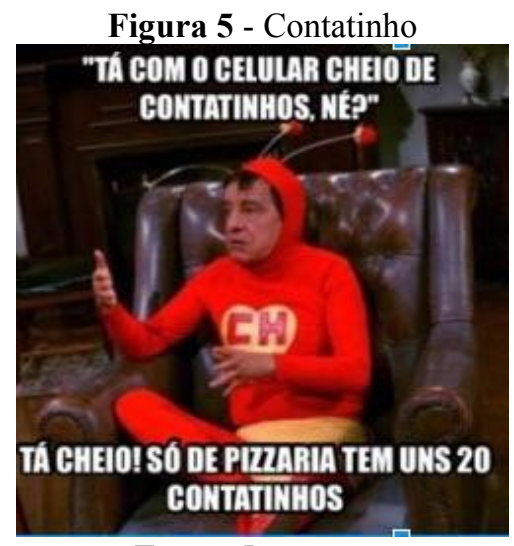

Fonte: Instagram.

"Contatinho", presente na Figura 5, corresponde tanto a um neologismo semântico quanto formal. Refere-se às pessoas que mantêm um contato afetivo-amoroso ou físico, consistindo em um neologismo semântico, além de ser uma função expressiva de diminutivo, ou seja, um neologismo formal (derivação sufixal). O sufixo '-inho' adicionado à base "contato" $-[\text { contato }]_{\text {substantivo }}+[\text { inho }]_{\text {sufixo }}>[\text { contatinho }]_{\text {substantivo }}-$ proporciona um sentido diferente daquele apresentado nos dicionários. 


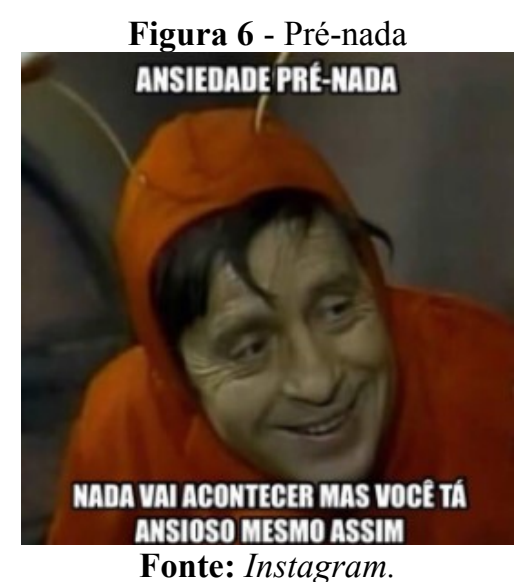

Na Figura 6, analisamos o neologismo formal "pré-nada", constituído a partir da ligação entre o prefixo 'pré-' e a base "nada": [pré $]_{\text {prefixo }}+[\text { nada }]_{\text {substantivo }}>$ [pré-nada $]_{\text {substantivo. }}$ A palavra neológica funciona do mesmo modo que o substantivo "pré-prova", por exemplo, e indica uma ansiedade de algo sem motivo aparente. Ainda observamos que o prefixo 'pré-' indica anterioridade/antecedência e juntamente com "nada" acarreta o sentido de anteceder a nada, estrutura não convencional no português.

A derivação prefixal não altera a classe gramatical das palavras derivadas e, nesse caso, o prefixo se mantém como substantivo da palavra primitiva. A classe da palavra "nada", todavia, não é tão simples, visto que pode ser classificada como advérbio, pronome indefinido e, em alguns contextos, como substantivo. Na Figura 6, por exemplo, em "nada vai acontecer", a referida palavra neológica é usada como pronome indefinido.

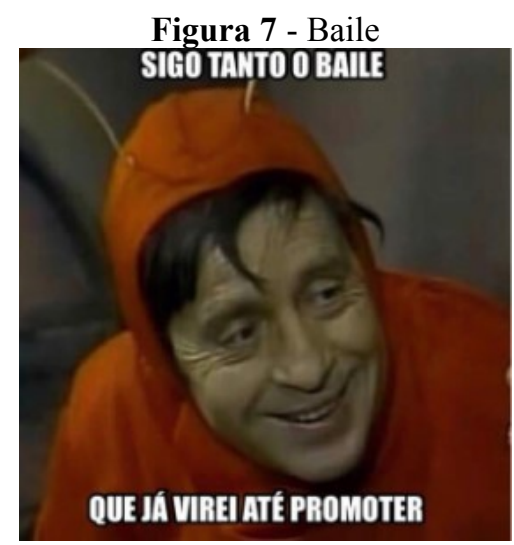

Fonte: Instagram.

De acordo com a Figura 7, temos um neologismo semântico. A expressão "seguir o baile", nesse caso, pode significar "seguir em frente", projetando um evento futuro, também "seguir outras pessoas", suas ideias, pensamentos ou ideologias. Esses sentidos ainda não estão registrados nas obras lexicográficas que apoiam a análise, mas, a partir do momento em que forem dicionarizados, essa expressão perde a sua natureza de novo.

O caso das Figuras 8 e 9 é bastante frequente e interessante, visto que se trata da mesma unidade neológica, porém, apresenta diferentes processos. Vejamos: 


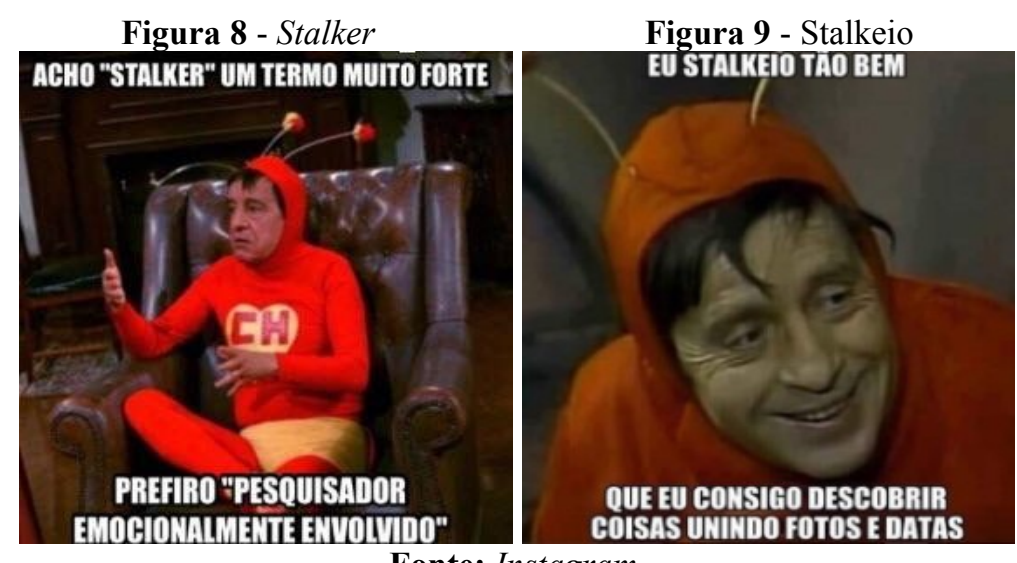

Fonte: Instagram.

"Stalker", na Figura 8, é um neologismo importado do inglês - estrangeirismo - que remete à pessoa que pratica a ação de perseguir, isto é, refere-se ao perseguidor. No português, embora o termo seja utilizado, em partes, com o mesmo significado, não é visto de modo negativo tal como é no inglês. No ambiente digital, contexto por nós analisado, stalker seria a pessoa que investiga a vida de outra por meio das redes sociais em função de motivos diversos, dentre eles, o amoroso.

Além do processo de neologismo importado, também consideramos a palavra, conforme apresentada na Figura 9, como neologismo formal, uma vez que ocorre o processo de

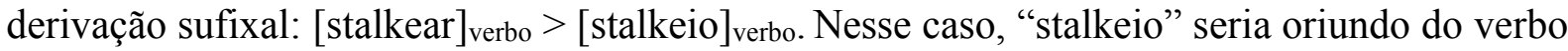
"stalkear", conjugado em número (singular), pessoa (primeira), tempo (presente) e modo (indicativo), portanto, segue o padrão de conjugação de verbos do sistema da língua portuguesa. Sobre isso, importa acrescentar que é possível encontrar outros exemplos do mesmo neologismo nas redes sociais, como "stalkeando".

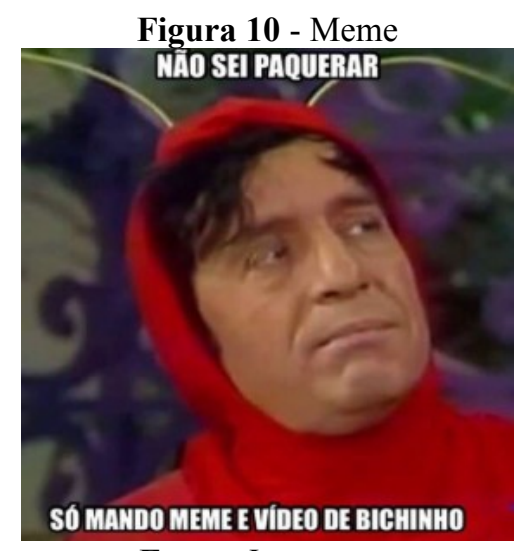

Fonte: Instagram.

O conceito "meme" foi criado pelo britânico Richard Dawkins, em 1976, na obra The Selfish Gene e dizia respeito, inicialmente, à evolução cultural humana. "Meme" se refere, nos dias atuais, a vídeos, imagens, gifs que apresentam um caráter humorístico, representando uma dada situação inserida em um contexto específico. Na Figura 10, é possível verificar, metalinguisticamente, o uso de "meme" em uma página do Instagram. Salientamos que a palavra "meme" não pode ser considerada um neologismo semântico, pois não pertence à língua

\footnotetext{
${ }^{7}$ stalker: a person who harasses or persecutes someone with unwanted and obsessive attention. Tradução nossa: "uma pessoa que assedia ou persegue alguém com atenção obsessiva e indesejada". Consultado em: https://en.oxforddictionaries.com/definition/stalker, cujo acesso foi em 21 de agosto de 2017.
} 
portuguesa. Logo, nesse contexto temos um empréstimo, cujo sentido foi modificado no decorrer do tempo para se adaptar ao contexto cultural.

\section{CONSIDERAÇÕES FINAIS}

A partir dos neologismos analisados, verificamos que a derivação é considerada o processo mais regular no sistema linguístico, isso porque os afixos são limitados na língua, tornando-se possível analisar, quantitativa e qualitativamente, os dados. Contudo, a composição torna-se um pouco mais difícil de delimitar, dado que o número de compostos que podem ocupar a posição de base é ilimitado, sendo menos previsível a ocorrência desse processo. À vista disso, o processo de derivação é o mais produtivo na língua, conforme nossos dados, enquanto que, via composição, é menos produtivo.

Há diferentes processos de derivação, que também podem ocorrer mais ou menos dependendo do objeto de estudo. Na nossa análise, vimos que a derivação sufixal se mostrou mais produtiva do que os outros tipos de derivação, sendo que os processos de derivação regressiva e imprópria (conversão), por sua vez, não ocorreram nenhuma vez, segundo nossos dados. Apesar de os estudos apontarem a derivação como o processo de formação de palavras de maior ocorrência e produtividade na língua e os dados de nossa pesquisa serem constituídos por um tipo de derivação, a sufixal, ressaltamos a importância do pesquisador em analisar as palavras, sejam elas neológicas ou não, de acordo com o contexto e a situação comunicativa de uma dada comunidade linguística, dada a heterogeneidade da língua.

\section{REFERÊNCIAS}

ALVES, I. M. Neologismo: criação lexical. Ática: São Paulo, 1990.

BARRETO, K.H. Os memes e as interações sociais na Internet: uma interface entre e estudos de face. 2015. Tese (Doutorado em Linguística) - Universidade Federal do Juiz de Fora, Juiz de Fora, 2015.

BASILIO. M. Formação e classes de palavras no português do Brasil. São Paulo: Contexto, 2004.

CABRÉ, M. T. La terminologia: teoria, metodologia, aplicaciones. Barcelona: Editorial Antártida/Empúries, 1993.

CÂMARA, JR., J. M. Dicionário de linguística e gramática. 36. ed. Petrópolis: Vozes, 2002. [1. ed. 1973, Dicionário de filologia e gramática referente à língua portuguesa].

CORREIA, M.; ALMEIDA, G. M. B. Neologia em português. São Paulo: Editora Parábola, 2012.

COSERIU, E. Sincronia, diacronia e história: o problema da mudança linguística. Tradução de Carlos Alberto da Fonseca e Mário Ferreira. Rio de Janeiro: Presença, EDUSP, 1979.

FERRAZ, A. P. Neologismos no português brasileiro contemporâneo: aplicação ao ensino de português para estrangeiros. Colóquio Diálogos com a Lusofonia, 2008, p. 114-132. 
FERREIRA, A. B. de H. Dicionário Online do Português. 2009. Disponível em: https://www.dicio.com.br/. Acesso em: 10 ago. 2017.

FONTANELLA, F. O que é um meme na Internet? Proposta para uma problemática da memesfera. Simpósio Nacional ABCiber. São Paulo, 2009.

GUILBERT, L. La creátivité lexicale. Paris: Larousse, 1975.

HOUAISS, A. Dicionário eletrônico Houaiss da língua portuguesa. Rio de Janeiro: Objetiva. Versão 3.0 [CD-ROM]. 2009.

ISO/FDIS 1087-1. Terminology work - Vocabulary. Part 1: Theory and application, 2000.

KEHDI, V. Formação de palavras em português. São Paulo: Editora Ática, Série Princípios, 2003.

MARCUSCHI, L. A. Da fala para a escrita: atividades de recontextualização. 8. ed. São Paulo: Cortez, 2007.

MARTELOTTA, M. E. Mudança linguística: uma abordagem baseada no uso. Coleção leituras introdutórias em linguagem, v.1. São Paulo: Editora Cortez, 2011.

MARTINS, É. F. O estudo dos neologismos semânticos no ensino de português: abordagem a partir de textos publicitários. 2015. Dissertação (Mestrado em Estudos Linguísticos) Faculdade de Letras, Universidade Federal de Minas Gerais. Belo Horizonte, 2015.

MICHAELIS. Dicionário Brasileiro da Língua Portuguesa. Disponível em: https://michaelis.uol.com.br/moderno-portugues/. Editora: Melhoramentos Ltda. Acesso em: 10 ago. 2017.

ROCHA, L. C. A. Estruturas Morfológicas do Português. 2. ed. São Paulo: Editora WMF Martins Fontes, 2008.

SANDMANN, A. J. Morfologia lexical: formação de palavras, ampliação do léxico, produtividade lexical. 2. ed. Coleção Repensando a língua portuguesa. São Paulo: Contexto, 1997.

SOUZA-E-SILVA, M. C. P.; KOCH, I. G. V. Linguística Aplicada ao Português: Morfologia. Ed 18, São Paulo: Cortez, 2012.

Recebido em: 19 de fevereiro de 2019.

Aceito em: 05 de setembro de 2019.

Publicado em Maio de 2020. 